\title{
Perilunate Fracture-Dislocation; Clinical Image
}

\section{Reza Minaei Noshahr ${ }^{1}$, Seyyed-Mohammad Qoreishi ${ }^{1}$, Ehsan Hakimi ${ }^{1}$, Seyyed Morteza Kazemi ${ }^{1,2}$, Siamak Shabani ${ }^{1}$, Peyman Zia Dehkordi ${ }^{1}$, Naser Ghanbari ${ }^{2}$, Mehdi Aarabi ${ }^{3,4}$ and Seyyed-Mohsen Hosseininejad ${ }^{1,3 *}$ \\ ${ }^{1}$ Bone, Joint and Related Tissue Research Center (BJRTrc), Shahid Beheshti University of Medical Sciences, Tehran, Iran \\ ${ }^{2}$ Associate Professor of Orthopedic Surgery, Shahid Beheshti University of Medical Sciences, Tehran, Iran}

${ }^{3}$ Golestan Rheumatology Research Center, Golestan University of Medical Sciences, Gorgan, Iran

${ }^{4}$ Department of Orthopedic Surgery, Toronto East General Hospital, 825 Coxwell Avenue, Toronto, ON M4C 3E7, Canada

*Corresponding author: Seyyed-Mohsen Hosseininejad, Orthopedic Resident, Bone, Joint and Related Tissue Research Center (BJRTrc), Shahid Beheshti University of Medical Sciences, Tehran, Iran

\begin{tabular}{|c|c|}
\hline ARTICLE INFO & ABSTRACT \\
\hline Received: 蔧 July 01, 2019 & Citation: Reza Minaei N, Seyyed-Mohammad Q, Ehsan H, Seyyed Morteza K, Seyyed- \\
\hline Published: 幽 July 05, 2019 & $\begin{array}{l}\text { Mohsen H, et al., Perilunate Fracture-Dislocation; Clinical Image. Biomed J Sci \& Tech Res } \\
\text { 19(3)-2019. BJSTR. MS.ID.003296. }\end{array}$ \\
\hline
\end{tabular}

\section{Presentation}

Perilunate fracture dislocations are rare with seven percentage of wrist pathologies but many of these injuries are not diagnosed well so that roughly $25 \%$ of perilunate dislocations being missed in clinics (Figure 1). The importance of diagnosing such injuries is highlighted by serious complications consists of chronic carpal instability, median nerve injury, lunate avascular necrosis, complex regional pain syndrome (CRPS) and posttraumatic wrist arthrosis [1-3]. Here, we report a case of a 42-year-old male presented to

our supreme orthopedic center, Akhtar Hospital, with right hand complex perilunate fracture dislocation treated by standard percutaneous pinning and dorsal screw fixation of scaphoid (Figure 2). The increased risk of complications with, performing an emergency salvage surgery in the acute setting for perilunate fracture dislocations could avert a patient from next repetitive operation. Our case presents a rare case of orthopedic emergency and indicate the importance of prompt diagnosis and intervention of perilunate injuries.
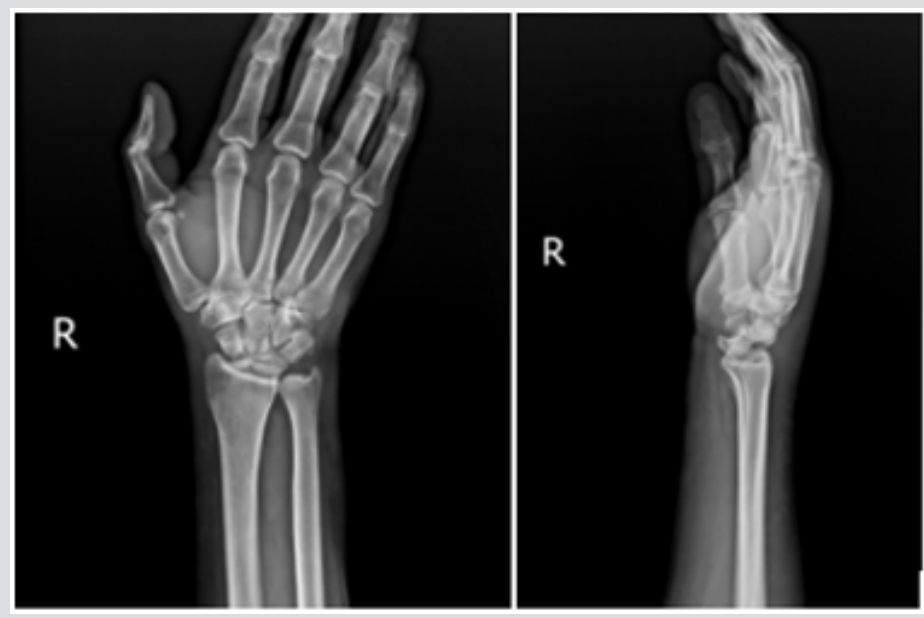

Figure 1: AP and lateral images of the initial radiographs taken in the secondary hospital showing perilunate dislocation and carpal misalignment beside scaphoid fracture. 

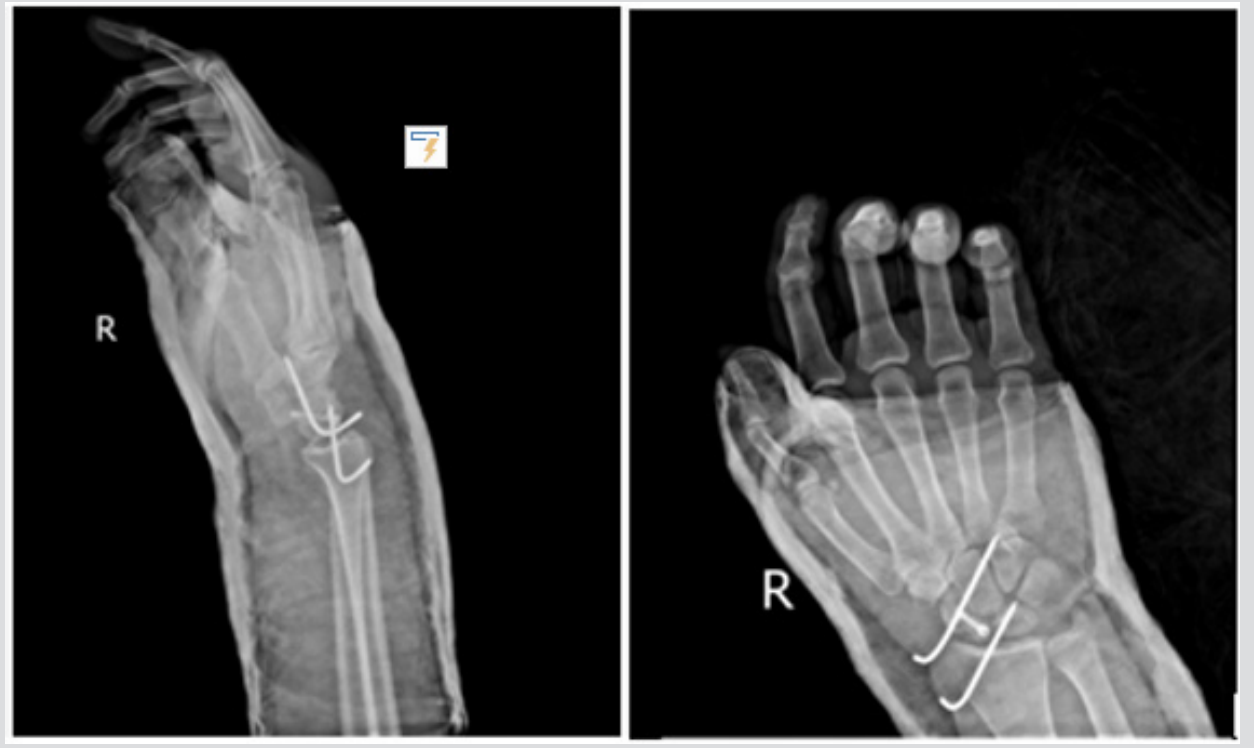

Figure 2: postoperative x-ray illustration scaphoid screw fixation and appropriate alignment of the carpal bone.

\section{References}

1. RC Muppavarapu, JT (2015) Capo Perilunate dislocations and fracture dislocations. Hand Clinics 31(3): 399-408.

2. T Muller, JJ Hidalgo Diaz, E Pire, G Prunières, S Facca, et al. (2017) Treatment of acute perilunate dislocations: ORIF versus proximal row carpectomy. Orthopaedics \& Traumatology: Surgery \& Research 103(1): 95-99.

3. MS Dhillon, S Prabhakar, K Bali, D Chouhan, V Kumar (2011) Functional outcome of neglected perilunate dislocations treated with open reduction and internal fixation. Indian Journal of Orthopaedics 45(5): 427-431.

\section{ISSN: 2574-1241}

DOI: 10.26717/BJSTR.2019.19.003296

Seyyed-Mohsen Hosseininejad. Biomed J Sci \& Tech Res

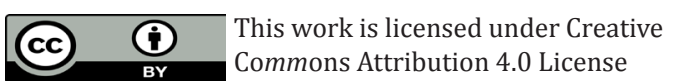

Submission Link: https://biomedres.us/submit-manuscript.php

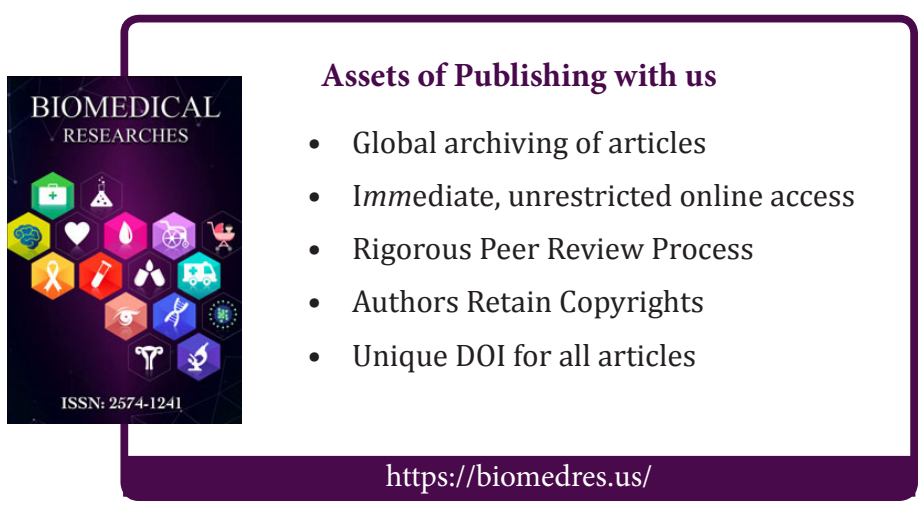

